\title{
Cost-consequence analysis of long-term prophylaxis in the treatment of von Willebrand disease in the Italian context
}

This article was published in the following Dove Press journal:

ClinicoEconomics and Outcomes Research

17 December 2014

Number of times this article has been viewed

\section{Piercarla Schinco' \\ Dorina Cultrera ${ }^{2}$ \\ Federica Valeri' \\ Alessandra Borchiellini' \\ Michela Mantuano 3 \\ Francesca Gorla ${ }^{3}$ \\ Alessia Savarese ${ }^{3}$ \\ Cristina Teruzzi ${ }^{3}$}

'Hemostasis and Thrombosis Unit, Molinette Hospital of Turin,

2Department of Hematology,

Hemophilia Regional Reference

Center, University Hospital of Catania,

${ }^{3}$ HEMAR-Health Economics, Market

Access and Reimbursement, Temas-A

Quintiles Company, Milan, Italy
Correspondence: Cristina Teruzzi Temas-A Quintiles Company, Cassina Plaza, via Roma 108, Edificio F - Scala 2, 20060 Cassina de' Pecchi (Milano), Italy Tel +390295794394

Fax +390295794435

Email cristina.teruzzi@quintiles.com
Purpose: Prophylaxis with von Willebrand factor (VWF)/factor VIII (FVIII) concentrates is a potential approach for patients with severe von Willebrand disease (VWD). As far as we are aware, to date there have been no pharmacoeconomic analyses in order to assess the economic impact of treatments for severe VWD. The analysis presented here estimates the cost-benefit ratio of VWF with a low FVIII content when compared with VWF/FVIII concentrates currently used in Italy for long-term prophylaxis in patients with severe VWD.

Methods: A cost-consequence analysis was undertaken to assess the economic impact of the treatment of severe VWD from the perspective both of the Italian National Health Service and society. The analysis was based on four case reports of long-term prophylaxis with VWD with VWF/FVIII concentrates and VWF with a low FVIII content. The costs per patient included direct and indirect costs for each treatment.

Results: Considering the four case reports, health care costs (without cost of treatment) and indirect costs per patient per year were lower with VWF with a low FVIII content than VWF/ FVIII concentrates. The total health care costs (without cost of treatment) and indirect costs avoided with VWF with a low FVIII content per patient per year ranged from $€ 2,295$ to $€ 17,530$ and from $€ 1,867$ to $€ 4,978$, respectively.

Conclusion: VWF with a low FVIII content seems to be a cost-effective treatment option for patients with severe VWD. Although the drug cost per se is higher, the use of VWF with a low FVIII content is associated with decreased consumption of hospital resources and fewer lost working days due to bleedings and consequently with an improvement of the quality of life of the patients.

Keywords: cost, VWF/FVIII concentrate, VWF with low FVIII content

\section{Introduction}

von Willebrand Disease (VWD) is the most common inherited bleeding disorder, with a prevalence of approximately $1 \%$ according to population studies, ${ }^{1}$ but clinically relevant cases have a tenfold lower prevalence. ${ }^{2}$ The 2011 Registro Nazionale delle Coagulopatie Congenite [National Registry of Congenital Coagulopathy], ${ }^{3}$ which reports data relative to 51 of 54 hemophilia centers in Italy, indicated that a total of 8,411 subjects are affected by coagulation disorders $-25 \%$ by VWD; $43 \%$ by hemophilia A; $9 \%$ by hemophilia B; $14 \%$ by disorders of other coagulation factors; and $9 \%$ by platelet disorders, carrier hemophilia $\mathrm{A} / \mathrm{B}$, or other disorders.

VWD is caused by a deficiency or abnormality of the von Willebrand factor (VWF), a multimeric adhesive glycoprotein with a key role in platelet adhesion; it is also the carrier and stabilizer of the factor VIII coagulant moiety (FVIII:C), thus indirectly 
contributes to the coagulation process. ${ }^{4}$ Type 1 and 2 VWD usually display a mild hemorrhagic phenotype (partial deficiency and qualitative defect, respectively), whereas patients with type 3 VWD (complete deficiency) are affected by a severe bleeding tendency.

The goal of the therapy for VWD is to correct the dual defects of hemostasis, abnormal platelet adhesion (due to low VWF adhesive activity) and abnormal intrinsic coagulation pathway (due to low FVIII:C). ${ }^{4}$ Two main options are available to manage VWD patients:

1. desmopressin acetate (DDAVP), which induces the release of endogenous VWF from endothelial compartments - type 1 patients and a fraction of type 2 patients usually respond

2. replacement therapy, which involves the transfusion of exogenous VWF contained in plasma-derived FVIII concentrates enriched with VWF (VWF/FVIII concentrates). VWF/FVIII concentrates are the first choice for the treatment of patients with type $3 \mathrm{VWD}$, for patients with type 2 B (because DDAVP can induce transient thrombocytopenia), and for those patients with type 1 and 2 who are unresponsive to DDAVP or have contraindications to its use.

Therapy with VWF/FVIII concentrates can be administered either on demand, through infusion of the amount of factors determined by the severity of the disease and by the patient's body weight, in order to stop occasional bleedings, or as prophylaxis in the more severe forms of the disease, through multiple weekly infusions, in order to control recurrent bleeding and to prevent life-threatening hemorrhages. ${ }^{5}$ Patients with severe forms of VWD may have frequent bleeding episodes, especially in those cases with FVIII levels below $20 \mathrm{IU} / \mathrm{dL}$, occurring in type $3 \mathrm{VWD}$ and in some cases with severe forms of type 1 and 2 . In these cases large doses of VWF/FVIII concentrates are required to control the bleeding. Prophylaxis with VWF/FVIII concentrates is considered a potential approach for those patients with severe bleeding tendency. ${ }^{5-8}$

The wide heterogeneity of the bleeding tendency that impacts heavily on quality of life (QoL) contributes to the uncertainties about the potential candidates, the optimal dose of concentrates, and regimes for prophylaxis. Furthermore, patients with VWD have an intact endogenous production of factor VIII (FVIII:C) and long-term exposure to VWFenriched FVIII concentrates may confer thromboembolic potential to prophylaxis. ${ }^{9-12}$ This observation suggests a particular care in the use of VWF/FVIII concentrates in patients with severe VWD and the need for regular FVIII:C level monitoring in order to maintain an appropriate hemostatic balance.

In this regard, there is a growing interest in replacement therapy with VWF concentrates almost devoid of FVIII, especially in severe VWD patients, in whom therapies with DDAVP and dual concentrates are not effective, not tolerated, or contraindicated (when a rise in FVIII concentration could predispose the patient to thrombotic events) in order to allow the control of bleeding episodes.

The objective of the analysis presented here is to assess the cost-benefit ratio of VWF with a low FVIII content (Wilfactin ${ }^{\circledR}$, Laboratoire Francais Du Fractionnement Et Des Biotechnologies, Les Ulis, France) when compared with the VWF/FVIII concentrates treatments (ie, Haemate ${ }^{\circledR}$ P, ZLB Behring, Marburg, Germany, and Fanhdi ${ }^{\circledR}$, Instituto Grifols, Barcelona, Spain) currently applied in Italy for long-term prophylaxis in patients with severe VWD, based on data from four case reports. The decision to use single case reports for the pharmacoeconomic analysis depended on two aspects: there are very few patients requiring long-term prophylaxis due to the difficulty in controlling bleeding episodes, and there are even fewer cases in which treatment with VWF with a low FVIII content has been utilized in Italy.

\section{Materials and methods}

A cost-consequence analysis was adopted in order to assess the economic impact of the treatment of VWD from the perspective of the National Health Service (NHS) and society.

The use of a cost-consequence approach depends on the fact that this analysis measures the health consequences without combining them into one summary effectiveness measure. This kind of analysis describes the value of a health care intervention and has the advantage of being more readily understandable and more likely to be applied by health care decision-makers, leaving the decision regarding the relative importance of different outcomes to the decision-maker. ${ }^{13,14}$

The analysis described in this paper was conducted on case reports in disaggregated form, as a pooled analysis would not give a robust statistical approach. The analysis has been based on four case reports of type $3(n=1)$, type $2 \mathrm{M}$ $(n=1)$ and type $1(n=2)$ VWD from hemophilia centers at the Molinette Hospital of Turin and University Hospital of Catania on the long-term treatment of VWD with VWF/ FVIII concentrates and VWF with a low FVIII content. These centers have clinical experience with patients with severe bleeding tendency receiving long-term prophylaxis (started at least 6 months before) who were switched from 
VWF/FVIII concentrates to VWF with a low FVIII content because of frequent recurrence of bleeding at the same sites, in order to obtain a better control of bleedings and a better efficacy of the therapy. Patients were included in the analysis if they had severe forms of VWD with periodic bleeding episodes, generally presented a low basal level of FVIII:C and FVIII:ristocetin-cofactor (Ri.CoF) before starting prophylaxis with VWF with a low FVIII content, and had been treated with VWF/FVIII concentrates.

The analysis includes direct costs associated with drug acquisition, hospital admissions, monitoring visits, and the cost of transfused units of red blood cell concentrates (packed red blood cells), and indirect costs evaluated as the number of working days lost per bleeding episode (loss of productivity).

In order to collect real-world evidence, a questionnaire addressed to clinicians experienced in the treatment of bleeding disorders was developed.

In the analysis, outcomes were evaluated in terms of treatment of minor or major bleeding episodes and related costs. The time horizon was 1 year.

The comparators used in the pharmacoeconomic evaluation were VWF/FVIII concentrates (Haemate ${ }^{\circledR} \mathrm{P}$ and Fanhdi ${ }^{\circledR}$ ), as these are the most used VWF/FVIII concentrates in the Italian clinical practice setting for long-term prophylaxis in the treatment of VWD. Both medicinal products, VWF/FVIII concentrates and VWF with a low FVIII content, are authorized in Italy for VWD. The concentrates were administered for prophylaxis at the following dosage: VWF/ FVIII concentrates $\left(\right.$ Fandhi $\left.^{\circledR}\right) 40 \mathrm{IU} / \mathrm{kg}$ three times per week; VWF/FVIII concentrates (Haemate ${ }^{\circledR} \mathrm{P}$ ) from 35 to $50 \mathrm{IU} / \mathrm{kg}$ three times per week; VWF with a low FVIII content from 30 to $50 \mathrm{IU} / \mathrm{kg}$ twice per week, and, in one case, $30 \mathrm{IU} / \mathrm{kg}$ three times per week. A single bleeding episode was treated with replacement therapy - that is, 30-50 IU/ $\mathrm{kg} /$ day per 3 days of concentrates, according to National Guidelines and Summary of Product Characteristics. ${ }^{1}$

The unitary cost of concentrates was obtained from Telematic Pharmaceutical Compendium 2013 http://www.farmadati.it/ and is equivalent to the ex-factory price that represents the maximum cost for the NHS structures. The cost of outpatients visits, transfusion of blood components, and laboratory and diagnostic tests are set in the "National Outpatient Tariffs Ministerial Decree [DM] 1997". The cost per unit of blood concentrate is set in the "DM 5th November 1996 and State-Regions Agreement 24th July 2003". The absorption of health care resources was calculated considering the Diagnosis Related Group (DRG) version 24 in order to assess DRG refund value for day hospital and for ordinary hospitalization. The cost of hospitalization and day hospital was derived from "National Hospital Tariffs DM 18th October, 2012".

Indirect costs were evaluated in terms of loss of productivity. The human capital method was adopted for the determination of the cost due to loss of productivity. Based on this approach, each day of absence from work, results in a simultaneous reduction in production. On the basis of this methodology, a value equivalent to the value generated from work for the same time period should be given to the working days lost due to illness. ${ }^{15}$

Here, all working days lost (in 1 year) due to diseaserelated medical and diagnostic investigations, are considered. The number of working days lost was estimated on the basis of the average annual income. ${ }^{16}$

\section{Results}

The direct and indirect costs are summarized in the tables.

Pharmaceutical cost includes both the yearly cost of treatment for long-term prophylaxis and the cost of treatment of bleeding episodes with concentrates (replacement therapy). Health care cost includes monitoring visits, diagnostic and laboratory tests, transfusion requirements, and hospitalizations (Table 1).

Although the cost of long-term prophylaxis was found to be higher with VWF with a low FVIII content, the cost per bleeding episodes per year was considerably reduced (in Case 1) or eliminated (in Cases 2-4) with VWF with a low FVIII content with respect to VWF/FVIII concentrates (Table 1, column 6: Cost of bleeding episodes per year). Indeed, in these four cases, VWF with a low FVIII content was able to reduce the number of bleeding episodes and consequently to minimize the cost of replacement therapy.

In all cases, health care costs were found to be substantially lower with VWF with a low FVIII content with respect to VWF/FVIII concentrates (Table 1, column 17: Health care cost per year without cost of treatment).

Indirect costs were evaluated in terms of number of working days lost (Table 2). These data show that replacement therapy with VWF with a low FVIII content was able to reduce the number of working days lost per bleeding episode together with the discomfort related to bleedings and, consequently, to improve the QoL in all these patients.

In one case report (Case 4), the cost of loss of productivity was not calculated, as the patient was retired. Despite this, the days of well-being lost due to illness may be considered and have an impact on the QoL of this patient. 
Table I Direct health care costs

\begin{tabular}{|c|c|c|c|c|c|c|c|c|}
\hline $\begin{array}{l}\text { Case } \\
\text { report }\end{array}$ & Drug & $\begin{array}{l}\text { Concentrates, } \\
\text { IU/year }\end{array}$ & $\begin{array}{l}\text { Cost of long- } \\
\text { term prophylaxis } \\
\text { treatment per } \\
\text { year (A) }\end{array}$ & $\begin{array}{l}\text { Bleeding } \\
\text { episodes } \\
\text { per year, } \\
\text { n }\end{array}$ & $\begin{array}{l}\text { Cost of } \\
\text { bleeding } \\
\text { episodes per } \\
\text { year (B) }\end{array}$ & $\begin{array}{l}\text { Pharmaceutical } \\
\text { costs }(C=A+B)\end{array}$ & $\begin{array}{l}\text { Outpatient- } \\
\text { monitoring } \\
\text { visits per } \\
\text { year, } n\end{array}$ & $\begin{array}{l}\text { Cost of } \\
\text { outpatient- } \\
\text { monitoring } \\
\text { visit (D) }\end{array}$ \\
\hline \multirow[t]{2}{*}{ I } & $\begin{array}{l}\text { VWF/FVIII } \\
\text { concentrate } \\
\left(\text { Fanhdi }^{\circledR}\right)\end{array}$ & 384,000 & $€ \mid 95,840$ & 12 & $€ 38,556$ & $€ 234,396$ & 30 & $€ 620$ \\
\hline & $\begin{array}{l}\text { VWF with } \\
\text { a low FVIII } \\
\text { content }\end{array}$ & 216,000 & $€ 235,38 \mathrm{I}$ & 2 & $€|3,73|$ & $€ 249, \mathrm{I} I 2$ & 16 & $€ 331$ \\
\hline \multirow[t]{2}{*}{2} & $\begin{array}{l}\text { VWF/FVIII } \\
\text { concentrate } \\
\left(\text { Haemate }{ }^{\circledR} \mathrm{P}\right)\end{array}$ & 360,000 & $€ 167,537$ & 30 & $€ 87,957$ & $€ 255,494$ & 16 & $€ 331$ \\
\hline & $\begin{array}{l}\text { VWF with } \\
\text { a low FVIII } \\
\text { content }\end{array}$ & 192,000 & $€ 209,228$ & - & - & $€ 209,228$ & 8 & $€ 165$ \\
\hline \multirow[t]{2}{*}{3} & $\begin{array}{l}\text { VWF/FVIII } \\
\text { concentrate } \\
\left(\text { Haemate }{ }^{\circledR} \mathrm{P}\right)\end{array}$ & 504,000 & $€ 234,552$ & 12 & $€ 58,638$ & $€ 293,190$ & 36 & $€ 744$ \\
\hline & $\begin{array}{l}\text { VWF with } \\
\text { a low FVIII } \\
\text { content }\end{array}$ & 288,000 & $€ 3 \mid 3,842$ & - & - & $€ 3 \mid 3,842$ & 12 & $€ 248$ \\
\hline \multirow[t]{2}{*}{4} & $\begin{array}{l}\text { VWF/FVIII } \\
\text { concentrate } \\
\left(\text { Haemate }{ }^{\circledR} \mathrm{P}\right)\end{array}$ & 504,000 & $€ 234,552$ & 2 & $€ 9,773$ & $€ 244,325$ & 8 & $€ 165$ \\
\hline & $\begin{array}{l}\text { VWF with } \\
\text { a low FVIII } \\
\text { content }\end{array}$ & 336,000 & $€ 366,148$ & - & - & $€ 366,148$ & 2 & $€ 4 I$ \\
\hline
\end{tabular}

Abbreviations: FVIII, factor VIII; VWF, von Willebrand factor; -, 0; IU, International Unit.

The results show data of pharmaceutical costs, health care costs, and indirect costs (loss of productivity) relative to each case (Tables 3-6 and Figures 1-4). These results show that the replacement therapy, both with VWF/FVIII concentrates and VWF with a low FVIII content, accounts for most of the total cost.

Although the dose to achieve full control of bleeding episodes depends on many factors, including in particular patient-related factors, it is possible to observe a minimization of doses of concentrates after the switch to VWF with a low
FVIII content (Table 1, column 3: Concentrates IU/year). In the four cases, long-term prophylaxis with VWF with a low FVIII content allowed the achievement of good control of bleedings, minimizing the cost of hospital admittances and transfusions of blood components. The reduction of these events with prophylaxis with VWF with a low FVIII content was found to afford a reduction in the health care costs per patient per year in all the case reports analyzed (Table 7, column 2: Total health care costs without pharmaceutical costs avoided with VWF with a low FVIII content per patient/year).

Table 2 Indirect costs

\begin{tabular}{|c|c|c|c|}
\hline Case report & Drug & $\begin{array}{l}\text { Work days lost per } \\
\text { bleeding episodes, } n\end{array}$ & $\begin{array}{l}\text { Total indirect cost - loss } \\
\text { of productivity per year }\end{array}$ \\
\hline \multirow[t]{2}{*}{ I } & VWF/FVIII concentrate $\left(\right.$ Fanhdi $\left.^{\circledR}\right)$ & 15 & $€ 2,334$ \\
\hline & VWF with a low FVIII content & 3 & $€ 467$ \\
\hline \multirow[t]{2}{*}{2} & VWF/FVIII concentrate $\left(\right.$ Haemate $\left.{ }^{\circledR} \mathrm{P}\right)$ & 26 & $€ 4,045$ \\
\hline & VWF with a low FVIII content & 2 & $€ 3 \mid I$ \\
\hline \multirow[t]{2}{*}{3} & VWF/FVIII concentrate $\left(\right.$ Haemate $\left.{ }^{\circledR} \mathrm{P}\right)$ & 36 & $€ 5,60$ I \\
\hline & VWF with a low FVIII content & 4 & $€ 622$ \\
\hline \multirow[t]{2}{*}{4} & VWF/FVIII concentrate $\left(\right.$ Haemate $\left.{ }^{\circledR} \mathrm{P}\right)$ & NA & NA \\
\hline & VWF with a low FVIII content & NA & NA \\
\hline
\end{tabular}

Abbreviations: FVIII, factor VIII; VWF, von Willebrand factor; NA, not available. 


\begin{tabular}{|c|c|c|c|c|c|c|c|c|}
\hline $\begin{array}{l}\text { Cost of } \\
\text { diagnostic and } \\
\text { laboratory } \\
\text { tests per year } \\
\text { (E) }\end{array}$ & $\begin{array}{l}\text { Days of } \\
\text { hospitalization } \\
\text { per year }\end{array}$ & $\begin{array}{l}\text { Number of } \\
\text { hospitalizations } \\
\text { per year }\end{array}$ & $\begin{array}{l}\text { Number of } \\
\text { hospital } \\
\text { admittances } \\
\text { (day hospital) }\end{array}$ & $\begin{array}{l}\text { Cost of } \\
\text { hospitalization } \\
\text { per year (F) }\end{array}$ & $\begin{array}{l}\text { Packed } \\
\text { red } \\
\text { blood } \\
\text { cells per } \\
\text { year }\end{array}$ & $\begin{array}{l}\text { Cost of } \\
\text { PRBC } \\
\text { per } \\
\text { year } \\
\text { (G) }\end{array}$ & $\begin{array}{l}\text { Health care } \\
\text { costs per year } \\
\text { without cost of } \\
\text { treatment }(H= \\
D+E+F+G)\end{array}$ & $\begin{array}{l}\text { Total health } \\
\text { care costs } \\
\text { per year } \\
(\mathrm{I}=\mathrm{C}+\mathrm{H})\end{array}$ \\
\hline- & 7 & 2 & 36 & $€|5,8| 0$ & 8 & $€|, 43|$ & $€ \mid 7,860$ & $€ 252,256$ \\
\hline- & - & - & - & - & - & - & $€ 331$ & $€ 249,442$ \\
\hline- & - & - & 12 & $€ 3,252$ & - & - & $€ 3,583$ & $€ 259,077$ \\
\hline- & - & - & - & - & - & - & $€ 165$ & $€ 209,393$ \\
\hline- & - & - & 4 & $€ I, 084$ & 4 & $€ 7 । 5$ & $€ 2,543$ & $€ 295,733$ \\
\hline- & - & - & - & - & - & - & $€ 248$ & $€ 3 \mid 4,089$ \\
\hline$€ 391$ & 4 & I & 5 & $€ 4,397$ & 2 & $€ 358$ & $€ 5,311$ & $€ 249,636$ \\
\hline$€ 55$ & - & - & - & - & - & - & $€ 96$ & $€ 366,245$ \\
\hline
\end{tabular}

Long-term prophylaxis with VWF with a low FVIII content, allowed in all cases the use of a lower quantity of this concentrate with respect to the VWF/FVIII concentrates. Nevertheless only in one case report (Case 2) was it possible to observe a reduction in pharmaceutical costs per patient per year (Table 7, column 3: Pharmaceutical cost avoided with VWF with a low FVIII content per patient/year).

Furthermore these results show a reduction in indirect costs, evaluated as a reduction of the number of working days lost per bleeding episode, with a related positive impact on QoL (Table 7, column 4: Indirect cost avoided with VWF with a low FVIII content per patient/year).

The analysis of these four case reports shows that VWF with a low FVIII content seems be a cost effective treatment option for patients with severe VWD phenotype, in whom therapies with DDAVP and dual concentrates are partially or not effective, non-tolerated or contra-indicated (when a rise of FVIII concentration could predispose the patient to thrombotic events), aimed to obtain a better control of bleeding episodes and consequently to improve the QoL.

Table 3 Costs in Case I

\begin{tabular}{|c|c|c|}
\hline \multirow[t]{2}{*}{ Type } & \multicolumn{2}{|l|}{ Value } \\
\hline & $\begin{array}{l}\text { VWF/FVIII } \\
\text { concentrate } \text { (Fanhdi }^{\circledR} \text { ) }\end{array}$ & $\begin{array}{l}\text { VWF with a low } \\
\text { FVIII content }\end{array}$ \\
\hline Cost of long-term prophylaxis treatment per year $(\mathrm{A})$ & $€ 195,840$ & $€ 235,381$ \\
\hline Cost of bleeding episodes (replacement therapy) per year (B) & $€ 38,556$ & $€|3,73|$ \\
\hline Pharmaceutical costs per year $(C=A+B)$ & $€ 234,396$ & $€ 249,112$ \\
\hline Health care costs (without pharmaceutical costs) per patient year (D) & $€ 17,860$ & $€ 331$ \\
\hline NHS perspective: total direct health cost per year $(E=C+D)$ & $€ 252,256$ & $€ 249,442$ \\
\hline Indirect cost per patient year (F) & $€ 2,334$ & $€ 467$ \\
\hline Social perspective total cost per patient year $(G=E+F)$ & $€ 254,590$ & $€ 249,909$ \\
\hline
\end{tabular}

Abbreviations: FVIII, factor VIII; VWF, von Willebrand factor; NHS, National Health System. 
Table 4 Costs in Case 2

\begin{tabular}{lll}
\hline Type & Value & \\
\cline { 2 - 3 } & $\begin{array}{l}\text { VWF/FVIII concentrate } \\
\text { (Haemate }{ }^{\circledR} \text { P) }\end{array}$ & $\begin{array}{c}\text { VWF with a low } \\
\text { FVIII content }\end{array}$ \\
\hline Cost of long-term prophylaxis treatment per year (A) & $€ 167,537$ & $€ 209,228$ \\
Cost of bleeding episodes (replacement therapy) per year (B) & $€ 87,957$ & $€ 0$ \\
Pharmaceutical costs per year (C = A + B) & $€ 255,494$ & $€ 209,228$ \\
Health care costs (without pharmaceutical costs) per patient year (D) & $€ 3,583$ & $€ 165$ \\
NHS perspective: total direct health cost per year (E = C + D) & $€ 259,077$ & $€ 209,393$ \\
Indirect cost-loss productivity per patient year (F) & $€ 4,045$ & $€ 3 I I$ \\
Social perspective total cost per patient year (G = E + F) & $€ 263,121$ & $€ 209,704$ \\
\hline
\end{tabular}

Abbreviations: FVIII, factor VIII; VWF, von Willebrand factor; NHS, National Health System.

Table 5 Costs in Case 3

\begin{tabular}{|c|c|c|}
\hline \multirow[t]{2}{*}{ Type } & \multicolumn{2}{|l|}{ Value } \\
\hline & $\begin{array}{l}\text { VWF/FVIII concentrate } \\
\text { (Haemate }{ }^{\circledR} \text { P) }\end{array}$ & $\begin{array}{l}\text { VWF with a low } \\
\text { FVIII content }\end{array}$ \\
\hline Cost of long-term prophylaxis treatment per year (A) & $€ 234,552$ & $€ 3 \mid 3,842$ \\
\hline Cost of bleeding episodes (replacement therapy) per year (B) & $€ 58,638$ & $€ 0$ \\
\hline Pharmaceutical costs per year $(C=A+B)$ & $€ 293,190$ & $€ 3 \mid 3,842$ \\
\hline Health care costs (without pharmaceutical costs) per patient year (D) & $€ 2,543$ & $€ 248$ \\
\hline NHS perspective: total direct health cost per year $(E=C+D)$ & $€ 295,733$ & $€ 314,089$ \\
\hline Indirect cost-loss productivity per patient year (F) & $€ 5,601$ & $€ 622$ \\
\hline Social perspective total cost per patient year $(\mathrm{G}=\mathrm{E}+\mathrm{F})$ & $€ 301,333$ & $€ 3|4,7| 2$ \\
\hline
\end{tabular}

Abbreviations: FVIII, factor VIII; VWF, von Willebrand factor; NHS, National Health System.

Table 6 Costs in Case 4

\begin{tabular}{|c|c|c|}
\hline \multirow[t]{2}{*}{ Type } & \multicolumn{2}{|l|}{ Value } \\
\hline & $\begin{array}{l}\text { VWF/FVIII concentrate } \\
\left(\text { Haemate }^{\circledR} \mathbf{P}\right)\end{array}$ & $\begin{array}{l}\text { VWF with a low } \\
\text { FVIII content }\end{array}$ \\
\hline Cost of long-term prophylaxis treatment per year (A) & $€ 234,552$ & $€ 366,148$ \\
\hline Cost of bleeding episodes (replacement therapy) per year (B) & $€ 9,773$ & $€ 0$ \\
\hline Pharmaceutical costs per year $(C=A+B)$ & $€ 244,325$ & $€ 366, \mid 48$ \\
\hline Health care costs (without pharmaceutical costs) per patient year (D) & $€ 5,311$ & $€ 96$ \\
\hline NHS perspective: total direct health cost per year $(E=C+D)$ & $€ 249,636$ & $€ 366,245$ \\
\hline Indirect cost-loss productivity per patient year (F) & NA & NA \\
\hline Social perspective total cost per patient year $(\mathrm{G}=\mathrm{E}+\mathrm{F})$ & NA & NA \\
\hline
\end{tabular}

Abbreviations: FVIII, factor VIII; VWF, von Willebrand factor, NHS, National Health System; NA, Not Available.

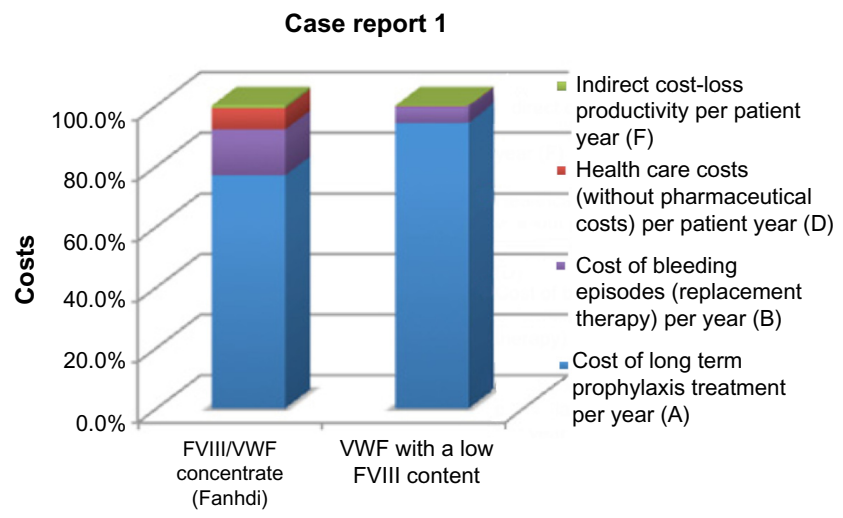

Figure I Resume of health care cost and indirect cost for Case report I. Abbreviations: FVIII, factor VIII; VWF, von Willebrand factor.

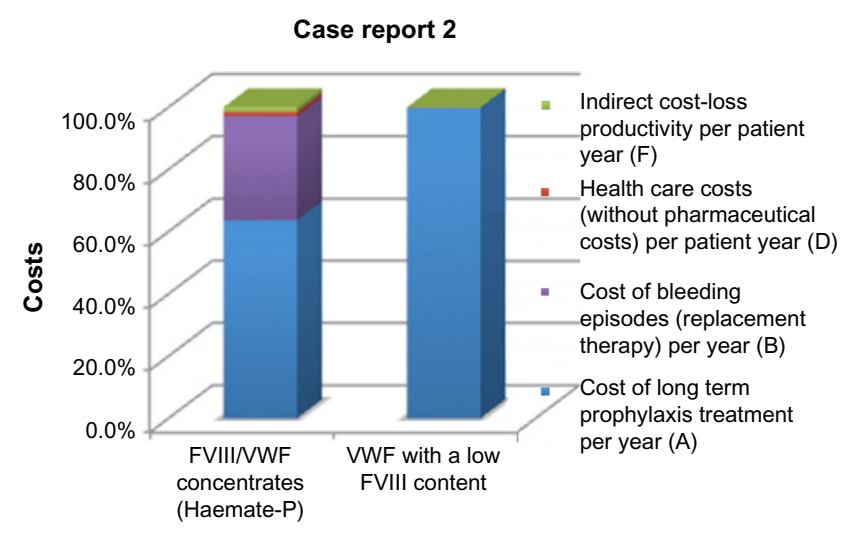

Figure 2 Resume of health care cost and indirect cost for Case report 2. Abbreviations: FVIII, factor VIII; VWF, von Willebrand factor. 


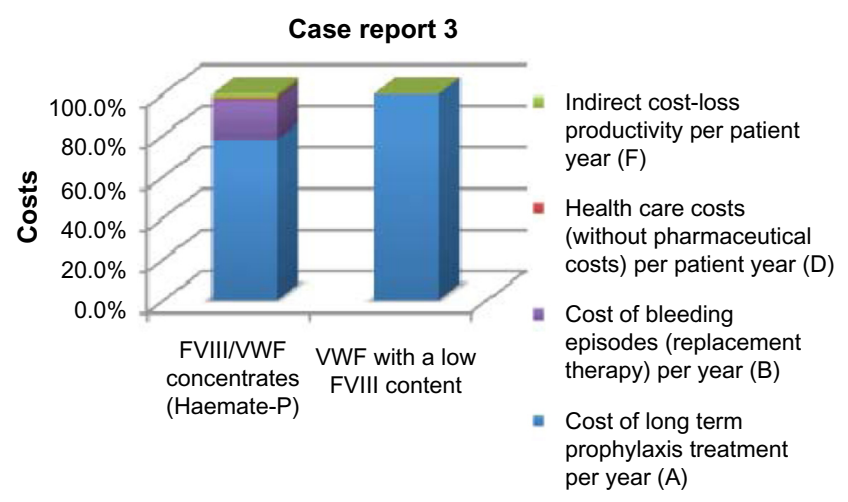

Figure 3 Resume of health care cost and indirect cost for Case report 3. Abbreviations: FVIII, factor VIII; VWF, von Willebrand factor.

\section{Discussion}

The treatment of a bleeding episode in VWD patients requires correction of the VWF deficiency (the defect in primary hemostasis) and the impaired secondary hemostasis (to increase the potentially low FVIII:C level). Apart from the administration of DDAVP in mild/moderate cases, replacement therapy with concentrates is the therapy of choice for bleeding situations or for short-term prophylaxis during surgery or clinical interventions, ${ }^{17-19}$ while for longterm prophylaxis few retrospective or prospective data are available to date. ${ }^{20-26}$

The greatest experience with secondary long-term prophylaxis in Italy has been with prophylaxis implemented in a cohort of Italian patients with VWD. In the study of Federici et al, ${ }^{24}$ among 89 patients who needed treatment with VWF/ FVIII concentrates during the previous 2 years because of one or more bleeding episodes, eleven were included in a prophylaxis program because of frequent recurrence of

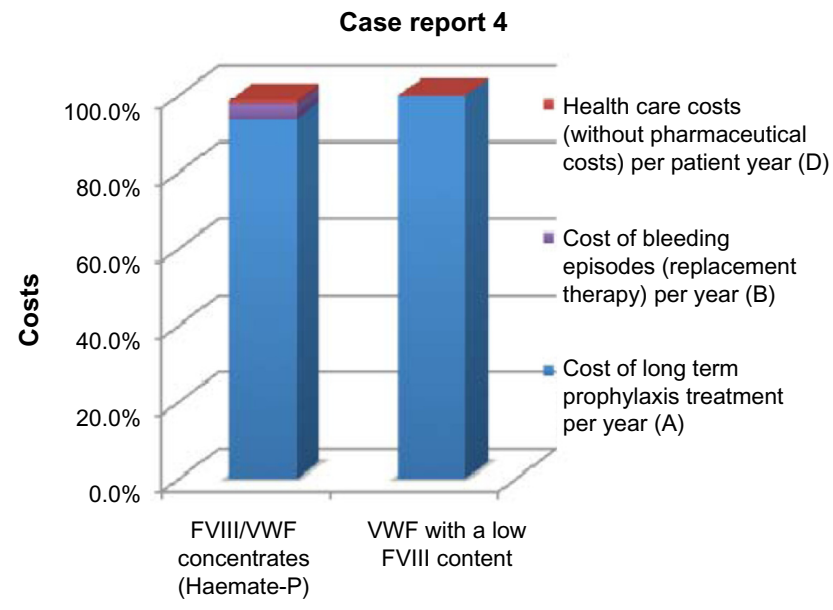

Figure 4 Resume of health care cost and indirect cost for Case report 4. Abbreviations: FVIII, factor VIII; VWF, von Willebrand factor. bleeding at the same sites. When prophylaxis was compared with previous on-demand regimens, in all the eleven cases, the annual total consumption of concentrates, the number of transfused blood units, and the number of days spent in hospital were found to be significantly reduced. Similar results were obtained in a Swedish study by Berntorp and Petrini. ${ }^{22}$ In that study, 35 patients with mostly type 3 VWD, prophylaxis was associated with a substantial decrease in the annual number of bleeding events.

As regards VWF with a low FVIII content, as far as we are aware, only one prospective study is available that includes, as additional experience, data on long-term prophylaxis in four patients with type 3 VWD. The study of Borel-Derlon et $\mathrm{al}^{26}$ investigated the efficacy and safety of VWF with a low FVIII content to treat patients with clinically severe VWD by merging the results of two comparable protocols conducted prospectively in five European (Italy is included) and twelve French centers. In that study, four patients received secondary long-term prophylaxis (of 17 months' duration) with VWF with a low FVIII content in order to prevent skin and musculoskeletal bleedings. After the long-term prophylaxis, the number of bleedings was substantially reduced.

In our analysis, we report on four adult patients (two with type 1 VWD, one with type 2M VWD, and one with type $3 \mathrm{VWD}$ ) who switched the long-term prophylaxis from VWF/FVIII concentrates to VWF with a low FVIII content in order to obtain better control of bleeding episodes and better efficacy of the treatment. In all these cases, VWF with a low FVIII content treatment was found to be an effective tolerated modality that was highly beneficial for the patients both in terms of a reduction in bleeding episodes and in terms of cost-benefit ratio.

To the best of our knowledge, this is the first analysis to have investigated the impact of secondary long-term therapies with VWF with a low FVIII content and the most used VWF/FVIII concentrates (ie, Haemate ${ }^{\circledR} \mathrm{P}$ and Fanhdi ${ }^{\circledR}$ ), in the Italian clinical practice setting, on clinical outcome (ie, bleeding frequency, hospitalizations) and indirect/social outcomes (reduction in number of working days lost per bleeding). As no previous studies have addressed this aspect, it is difficult to make any comparison. However long-term prophylaxis with VWF with a low FVIII content was found to be associated with a significant reduction of the number of days spent on patient care (hospitalizations, outpatient visits, laboratory and other diagnostic examinations) together with a decrease in total concentrate consumption for bleedings, in all case reports considered. 
Table 7 Net impact of switch from VWF/FVIII concentrates to VWF with a low FVIII content

\begin{tabular}{llll}
\hline Case & $\begin{array}{l}\text { Total health care cost, without } \\
\text { pharmaceutical cost avoided with VWF } \\
\text { with a low FVIII content per patient/year }\end{array}$ & $\begin{array}{l}\text { Pharmaceutical cost avoided } \\
\text { with VWF with a low FVIII } \\
\text { content per patient/year }\end{array}$ & $\begin{array}{l}\text { Indirect cost avoided with } \\
\text { VWF with a low FVIII } \\
\text { content per patient/year }\end{array}$ \\
\hline 1 & $€ I 7,530$ & $-€ I 4,716$ & $€ I, 867$ \\
2 & $€ 3,4 I 7$ & $€ 46,266$ & $€ 3,734$ \\
3 & $€ 2,295$ & $-€ 20,652$ & $€ 4,978$ \\
4 & $€ 5,215$ & $-€ I 21,824$ & NA \\
\hline
\end{tabular}

Abbreviations: FVIII, factor VIII; VWF, von Willebrand factor; NA, not available.

The main limitation of the analysis is that it was based on single case reports, because few patients are in long-term prophylaxis with VWF/FVIII concentrates or VWF with a low FVIII content in the Italian clinical practice setting. Further case reports of long-term prophylaxis treatment with concentrates in VWD are necessary to support the results obtained in this primary analysis.

Despite the limitations of the use of single case reports for the analysis, it seems that long-term prophylaxis with VWF with a low FVIII content is likely to be a cost-effective approach with a favorable impact on the reduction of health care resource consumption and that also allows the patient to resume their normal life and work activities (the number of working days lost was found to be considerably reduced after switching to VWF with a low FVIII content [Table 2, column 2]). These data are consistent with the improvement in the QoL of the patients, which is a primary objective of any health care intervention.

\section{Conclusion}

This analysis shows that VWF with a low FVIII content was more able to control bleeding episodes and, consequently, to reduce the health care interventions necessary, with respect to VWF/FVIII concentrates, in four patients with severe VWD. Although these are preliminary data, they are likely to contribute to establishing the role of specific concentrates for the long-term prophylaxis of severe cases of VWD. Nevertheless, a large collection of clinical data is needed so as to assess regimens, comparative effectiveness, and the cost-effectiveness of long-term prophylaxis treatment in patients with VWD, in order to evaluate which of the available concentrates has a better cost-benefit ratio in patients with severe VWD.

\section{Author contributions}

All authors made substantial contributions to the conception and design of the research and to the acquisition, analysis, and interpretation of data; drafted the article and revised it critically for important intellectual content; and gave their final approval of the version to be published.

\section{Acknowledgment}

The research was supported by an unconditional grant from Laboratoire Francais Du Fractionnement Et Des Biotechnologies.

\section{Disclosure}

The authors declare no conflicts of interest in this work.

\section{References}

1. Federici AB, Castaman G, Mannucci PM. Italian Association of Hemophilia Centers (AICE). Guidelines for the diagnosis and management of von Willebrand disease in Italy. Haemophilia. 2002;8(5):607-621.

2. Castaman G, Eikenboom JC, Bertina RM, Rodeghiero F. Inconsistency of association between type 1 von Willebrand disease phenotype and genotype in families identified in an epidemiological investigation. Thromb Haemost. 1999;82(3):1065-1070.

3. Abbonizio F, Giampaolo A, Arcieri R, Hassan HJ, Associazione Italiana Centri Emofilia (AICE). Registro Nazionale delle Coagulopatie Congenite: Rapporto 2011 [National Registry of Congenital Coagulopathy: 2011 Report]. Rome: Istituto Superiore di Sanità; 2012. Available from: http://www.iss.it/binary/publ/cont/12_55_web.pdf. Accessed October 13, 2014

4. Castaman G, Federici AB, Rodeghiero F, Mannucci PM. Von Willebrand's disease in the year 2003: towards the complete identification of gene defects for correct diagnosis and treatment. Haematologica. 2003;88(1):94-108.

5. Castaman G, Goodeve A, Eikenboom J; European Group on von Willebrand Disease. Principles of care for the diagnosis and treatment of von Willebrand disease. Haematologica. 2013;98(5):667-674.

6. Mannucci PM. Treatment of von Willebrand's Disease. $N$ Engl J Med. 2004;351(7):683-694.

7. Pasi KJ, Collins PW, Keeling DM, et al. Management of von Willebrand disease: a guideline from the UK Haemophilia Centre Doctors' Organization. Haemophilia. 2004;10(3):218-231.

8. James PD, Lillicrap DP. The diagnosis and management of von Willebrand disease in Canada. Semin Thromb Hemost. 2011;37(5): 522-527.

9. Kyrle PA, Minar E, Hirschl M, et al. High plasma levels of factor VIII and the risk of recurrent venous thromboembolism. $N$ Engl J Med. 2000;343(7):457-462.

10. Makris M, Colvin B, Gupta V, Schields ML, Smith MP. Venous thrombosis following the use of intermediate purity FVIII concentrate to treat patients with von Willebrand's disease. Thromb Haemost. 2002;88(3): 387-388.

11. Mannucci PM. Venous thromboembolism in von Willebrand disease. Thromb Haemost. 2002;88(3):378-379. 
12. Franchini M, Krampera M, Veneri D. Deep vein thrombosis after orthopedic surgery in a patient with type 1 von Willebrand disease and mutations in the MTHFR and beta-fibrinogen genes. Thromb Haemost. 2003;90(5):963-964.

13. Mauskopf JA, Paul JE, Grant DM, Stergachis A. The role of cost-consequence analysis in healthcare decision-making. Pharmacoeconomics. 1998;13(3):277-288.

14. Freemantle N, Mason J. Not playing with a full DEC: why development and evaluation committee methods for appraising new drugs may be inadequate. BMJ. 1999;318(7196):1480-1482.

15. Drummond MF, Sculpher MJ, Torrance GW, O’Brien BJ, Stoddart GL. Methods for the Economic Evaluation of Health Care Programmes. 2nd ed. Oxford: Oxford University Press; 1997.

16. Bank of Italy. Annual Report of Bank of Italy on 2012. May 31, 2013.

17. Bolton-Maggs PH, Lillicrap D, Goudemand J, Berntorp E. von Willebrand disease update: diagnostic and treatment dilemmas. Haemophilia. 2008;14 Suppl 3:56-61.

18. Nichols WL, Hultin MB, James AH, et al. von Willebrand disease (VWD): evidence-based diagnosis and management guidelines, the National Heart, Lung, and Blood Institute (NHLBI) Expert Panel report (USA). Haemophilia. 2008;14(2):171-232.

19. James AH, Kouides PA, Abdul-Kadir R, et al. Von Willebrand disease and other bleeding disorders in women: consensus on diagnosis and management from an international expert panel. Am J Obstet Gynecol. 2009;201(1):12. e1-e8.
20. Halimeh S, Krümpel A, Rott H, et al. Long-term secondary prophylaxis in children, adolescents and young adults with von Willebrand disease. Results of a cohort study. Thromb Haemost. 2011;105(4): 597-604.

21. Abshire TC, Federici AB, Alvárez MT, et al; VWD PN. Prophylaxis in severe forms of von Willebrand's disease: results from the von Willebrand Disease Prophylaxis Network (VWD PN). Haemophilia. 2013;19(1):76-81.

22. Berntorp E, Petrini P. Long-term prophylaxis in von Willebrand disease. Blood Coagul Fibrinolysis. 2005;16 Suppl 1:S23-S26.

23. Coppola A, Cimino E, Conca P, et al. Long-term prophylaxis with intermediate-purity factor VIII concentrate (Haemate P) in a patient with type 3 von Willebrand disease and recurrent gastrointestinal bleeding. Haemophilia. 2006;12(1):90-94.

24. Federici AB, Gianniello F, Mannucci PM. Secondary long-term prophilaxis in von Willebrand disease: an Italian cohort study. Haematologica Reports. 2005;1(6)15-20.

25. Federici AB. Highly purified VWF/FVIII concentrates in the treatment and prophylaxis of von Willebrand disease: the PRO. WILL Study. Haemophilia. 2007;13 Suppl 5:15-24.

26. Borel-Derlon A, Federici AB, Roussel-Robert V, et al. Treatment of severe von Willebrand disease with a high-purity von Willebrand factor concentrate (Wilfactin): a prospective study of 50 patients. J Thromb Haemost. 2007;5(6):1115-1124.
ClinicoEconomics and Outcomes Research

\section{Publish your work in this journal}

ClinicoEconomics \& Outcomes Research is an international, peerreviewed open-access journal focusing on Health Technology Assessment, Pharmacoeconomics and Outcomes Research in the areas of diagnosis, medical devices, and clinical, surgical and pharmacologica intervention. The economic impact of health policy and health systems

\section{Dovepress}

organization also constitute important areas of coverage. The manuscript management system is completely online and includes a very quick and fair peer-review system, which is all easy to use. Visit http://www.dovepress.com/testimonials.php to read real quotes from published authors. 